\title{
Genetic variability of broodstocks of restocking programs in Brazil
}

\section{Variabilidad genética de lotes de reproductores de programas de repoblación en Brasil}

\author{
Nelson Lopera-Barrero, ${ }^{1 *}$ Ph.D, Ed Lima, ${ }^{1}$ Zoot, Luiz Filho, ${ }^{2}$ Ph.D, Elenice Goes, ${ }^{2}$ M.Sc, \\ Pedro Castro, ${ }^{2}$ Zoot, Aline Zardin, ${ }^{2}$ M.Sc, Angela Poveda-Parra, ${ }^{1}$ Ph.D, \\ Ricardo Ribeiro², Ph.D.
}

\begin{abstract}
${ }^{1}$ Universidade Estadual de Londrina, Departamento de Zootecnia, Programa de Pós-Graduação em Ciência Animal, Rod. Celso Garcia Cid Pr 445 hm 380 Campus Universitário, Londrina, Brasil. 2Universidade Estadual de Maringá, Departamento de Zootecnia, Programa de Pós-Graduação em Zootecnia, Avenida Colombo 5790 Jardim Universitário, Maringá, Brasil. *Correspondence: nmlopera@uel.br
\end{abstract}

Received: August 2014; Accepted: February 2015.

\begin{abstract}
Objective. The aim of this study was evaluate the genetic diversity of the following broodstocks: piapara (Leporinus elongatus), dourado (Salminus brasiliensis), jundiá (Rhamdia quelen) and cachara (Pseudoplatystoma fasciatum) already useful for restocking programs in the Paranapanema, Iguaçu and Paraná Brazilian Rivers. Materials and methods. Samples from the caudal fin of 122 fish were analyzed. DNA was extracted by $\mathrm{NaCl}$ protocol. PCR products were separated by a horizontal agarose gel electrophoresis. The fragments were visualized by staining with ethidium bromide. Results. The amplification of 25 primers generated different fragments in studied species that allowed characterizing 440 fragments of 100-2900 bp. High percentage of polymorphic fragments (66.67 to 86.29), Shannon index ( 0.365 to 0.486$)$ and genetic diversity of $\mathrm{Nei}(0.248$ to 0.331$)$ were detected. Conclusions. The level of genetic variability in the broodstocks was adequate for allowing their use in restocking programs in the studied Rivers. However, periodical monitoring studies of genetic variability in these stocks, the mating system, reproductive system and general management must be made to guarantee the preservation of wild populations.
\end{abstract}

Key words: Genetic conservation, Leporinus elongatus, Pseudoplatystoma fasciatum, Rhamdia quelen, Salminus brasiliensis (Source: DeSC, CAB Thesaurus).

\section{RESUMEN}

Objetivo. El objetivo de este estudio fue evaluar la diversidad genética de los siguientes lotes de reproductores: piapara (Leporinus elongatus), dourado (Salminus brasiliensis), jundiá (Rhamdia quelen) y cachara (Pseudoplatystoma fasciatum) utilizados para programas de repoblación en los ríos brasileños Paranapanema, Iguaçu y Paraná. Materiales y métodos. Muestras de aleta caudal de 122 peces fueron analizadas. El ADN fue extraído por el protocolo de $\mathrm{NaCl}$. Los productos de PCR fueron separados por electroforesis horizontal en gel de agarosa. Los fragmentos fueron visualizados por marcación con bromuro de etidio. Resultados. La amplificación de los 25 iniciadores produjo diferentes fragmentos en las especies estudiadas que permitieron caracterizar 440 fragmentos de 100 a 2900 pb. Fueron detectados un alto porcentaje de fragmentos polimórficos (66.67 a 86.29), de 
índice de Shannon (0.365 a 0.486) y de diversidad genética de Nei (0.248 a 0.331). Conclusiones. El nivel de variabilidad genética en los lotes de reproductores fue adecuado para su utilización en programas de repoblación en los ríos estudiados. Sin embargo, estudios de monitoreo periódico de la variabilidad genética en esos lotes, del sistema de cruzamiento, del sistema reproductivo y del manejo general deben ser realizados para garantizar la preservación de las populaciones naturales.

Palabras clave: Conservación genética, Leporinus elongatus, Pseudoplatystoma fasciatum, Rhamdia quelen, Salminus brasiliensis (Fuente: DeSC, CAB Thesaurus).

\section{INTRODUCTION}

In the last seven years, fishing of the world aquatic organisms has pointed out toward decreases and stabilization. In 2005 and 2010, only 92.478 .416 and 88.970 .124 tons were, respectively, captured, which means a reduction of 3.508.292 tons. In 2011, in contrast, 93.494.340 tons had 4.524.216 tons higher than in 2010 (1). The fish farming, otherwise, has been more significant. For example, in 2005 and 2010 the growth was higher than the catching, when there was an increase from 57.815.836 to 78.028.539 tons, respectively, representing a net output of 20.212.703 tons. In 2011, furthermore, 83.675.661 tons of fish were raised; an output of 5.647.122 tons higher than in 2010 (1).

In Brazil, based on data from the Aquaculture and Fisheries Ministry (2), the fishing exploitation had an increase from 785.366 in 2010 to 803.270 tons in 2011 , or $2.3 \%$. Otherwise, the fish farming increased from 479.398 in 2010 to 628.704 tons in 2011 , or $31.1 \%$. These data suggest an overlap of fish farming on fishing exploitation in the next years as well as detected in other segments of the animal production (3). The piapara (Leporinus elongatus), dourado (Salminus brasiliensis), jundiá (Rhamdia quelen) and cachara (Pseudoplatystoma fasciatum) species has been highlighted because they are present in several Brazilian basins (4) with several factors encouraging their farming as the good growth and performance, the easy reproduction and the rusticity $(5-8)$. These factors have impacted the Brazilian market of fish. For example, in 2011 were produced 4309.3 and 1747.3 tons of Rhamdia and Leporinus (2).

Other factors, however, as the water pollution, deforestation, habitat destruction, overfishing, introduction of exotic species and river damming $(9,10)$ has been reducing the wild populations of these freshwater fish in Brazil. Among the several decisions made to mitigate the reduction of the wild populations of fish, we highlight the restocking programs (11). Despite they have been applied in Brazil for decades, researches about their genetic and environmental efficiency have still to be done (12). Based on Kalinowski et al (13), the goals of such programs for

\section{INTRODUCCIÓN}

En los últimos siete años, la pesca en el mundo de organismos acuáticos apunta a incrementos y estabilización. Entre 2005 y 2010, sólo 92.478 .416 Y 88.970.124 t fueron, respectivamente, capturadas, lo cual significa una reducción de 3.508.292 t. En 2011, en contraste, 93.494.340 toneladas fueron 4..524.216 toneladas más que en 2010 (1). La piscicultura, por otro lado, ha sido más significativa. Por ejemplo, en 2005 y 2010 el crecimiento fue mayor que la pesca, cuando hubo un incremento de 57.815 .836 a 78.028 .539 t, respectivamente, representando una producción de 20.212.703 t. En 2011, asimismo, 83.675.661 t de pescado fueron cultivadas; una producción de 5.647.122 t más que en 2010 (1).

En Brasil, basados en datos del Ministerio de Acuicultura y Pesca (2), la explotación de pesca tuvo un incremento de 785.366 en 2010 a 803.270 t en 2011 , o $2.3 \%$. De otra manera, la piscicultura creció de 479.398 en 2010 a 628.704 t en 2011 , o $31.1 \%$. Éstos datos sugieren una sobre posición de piscicultura sobre la explotación de pesca en los próximos años así como se ha detectado en otro segmento de producción animal (3). Las especies de piapara (Leporinus elongatus), dourado (Salminus brasiliensis), jundiá (Rhamdia quelen) y cachara (Pseudoplatystoma fasciatum) se han resaltado porque están presentes en varias cuencas brasileñas (4) con diversos factores que estimulan su cultivo como el buen crecimiento y rendimiento, la fácil reproducción y la rusticidade (5-8). Estos factores han impactado el mercado brasilero para los peces. Por ejemplo en el 2011 se produjeron 4309.3 y 1747.3 toneladas de Rhamdia y Leporinus (2).

Otros factores, sin embargo, como la polución del agua, deforestación, destrucción del hábitat, sobrepesca, introducción de especies exóticas y represamiento de los ríos $(9,10)$ han reducido las poblaciones naturales de esos peces de agua dulce en el Brasil. Entre las decisiones tomadas para mitigar la reducción de las poblaciones naturales de peces, resaltamos los programas de repoblación (11). Aunque han sido aplicados en Brasil por décadas, las investigaciones sobre su eficiencia genética y ambiental no se han hecho 
endangered species have been to avoid the complete losses of gene clusters, preserve as much as possible the genetic diversity and reach the first step without compromise the survivorship of the populations in a long term. Many programs, however, were unsuccessful because the mismanagement of parental stocks (11) and the genetic non-monitoring. Thus, the genetic evaluation of the stocks for restocking has to be done. The molecular markers have been one of the most useful methods to approach the genetic diversity and the population structure of the various species and fish lines $(14,15)$.

The aim of the current study was to evaluate the genetic diversity of the piapara (Leporinus elongatus), dourado (Salminus brasiliensis), jundiá (Rhamdia quelen) and cachara (Pseudoplatystoma fasciatum) broodstocks in restocking programs applied in the Paranapanema, Iguaçu and Paraná Brazilian Rivers.

\section{MATERIAL AND METHODS}

Study site and sample collection. Caudal fins samples from broodstocks of the species Leporinus elongatus (30 samples), Salminus brasiliensis (30 samples), Rhamdia quelen (36 samples) and Pseudoplatystoma fasciatum (26 samples) were collected. These broodstocks are originally from collections carried in the Paranapanema River São Paulo State (S $22^{\circ} 26^{\prime}$ and $47^{\circ} 54^{\prime} \mathrm{W}$ - L. elongatus and $S$. brasiliensis), Iguacu River Paraná State (S $25^{\circ} 40^{\prime}$ and $54^{\circ} 26^{\prime} \mathrm{W}-R$. quelen) and Paraná river - Parana State (S $23^{\circ} 16^{\prime}$ and $53^{\circ} 43^{\prime} \mathrm{W}-\mathrm{P}$. fasciatum), Brazil. All these fish will be used to compose the restocking programs in these respective rivers.

Experimental procedure. The DNA was extracted using the protocol described by LoperaBarrero et al (16). The DNA extracted was quantified in the Shimadzu spectrophotometer using the absorbance of $260 \mathrm{~nm}$. The samples were diluted to $10 \mathrm{ng} / \mu \mathrm{L}$, and the DNA quality was evaluated in $1 \%$ agarose gel electrophorese using a buffer TBE $1 \times(500 \mathrm{mM}$ Tris- $\mathrm{HCl}, 60 \mathrm{mM}$ boric acid and $83 \mathrm{mM}$ EDTA) at $70 \mathrm{~V}$ for one hour. The gel was visualized under UV radiation after treatment with ethidium bromite $(0.5 \mathrm{mg} / \mathrm{ml})$ for one hour. Thereafter, the image was photographed using the program Kodak EDAS (Kodak 1D Image Analysis 3.5, EUA).

The DNA was amplified in volume of reaction of $15 \mu \mathrm{L}$ using the buffer $1 \mathrm{X}$ Tris $\mathrm{KCl}, 2 \mathrm{mM}$ of $\mathrm{MgCl}_{2}$, $0.46 \mu \mathrm{M}$ of primer, $0.2 \mathrm{mM}$ of every dNTP, one unity of Platinum Taq DNA Polymerase (Invitrogen, Carlsbad, EUA), and $10 \mathrm{ng}$ of target DNA.
(12). De acuerdo con Kalinowski et al (13), las metas de dichos programas para especies en peligro de extinción ha sido evitar las pérdidas completas de conjuntos de genes, preservar en lo más posible la diversidad genética y llegar el primer paso sin comprometer la supervivencia de las poblaciones a largo plazo. Muchos programas, sin embargo, no han sido exitosos debido al mal manejo de los lotes parentales (11) y a la falta de monitoreo genético. Así, la evaluación genética de los lotes para repoblación debe ser realizada. Los marcadores moleculares han sido uno de los métodos más útiles para abordar la diversidad genética y la estructura poblacional de varias especies y líneas de peces $(14,15)$

El objetivo del presente estudio fue evaluar la diversidad genética de lotes de reproductores de piapara (Leporinus elongatus), dourado (Salminus brasiliensis), jundiá (Rhamdia quelen) y cachara (Pseudoplatystoma fasciatum) en programas de repoblación aplicados en los ríos Brasileños Paranapanema, Iguacu y Paraná.

\section{MATERIALES Y MÉTODOS}

Locación del estudio y recolección de muestras. Fueron recolectadas muestras de aleta caudal de estoques de reproductores de las espécies Leporinus elongatus (30 muestras), Salminus brasiliensis (30 muestras), Rhamdia quelen (36 muestras) y Pseudoplatystoma fasciatum (26 muestras). Esos estoques de reproductores son originarios de recolectas realizadas en el río Paranapanema - Estado de São Paulo (S $22^{\circ} 26^{\prime}$ y $47^{\circ} 54^{\prime} \mathrm{W}-L$. elongatus y $S$. brasiliensis), río Iguaçu - Estado del Paraná (S $25^{\circ}$ $40^{\prime}$ y $54^{\circ} 26^{\prime} \mathrm{W}-R$. quelen) y río Paraná - Estado del Paraná (S $23^{\circ} 16^{\prime}$ y $53^{\circ} 43^{\prime}$ W - P. fasciatum), Brasil. Todos estos peces serán utilizados para componer los programas de repoblación en estos respectivos ríos.

Procedimiento experimental. EI ADN fue extraído utilizando el protocolo descrito por Lopera-Barrero et al (16). El ADN extraído se cuantificó en un espectrofotómetro Shimadzu utilizando la absorbancia de $260 \mathrm{~nm}$. Las muestras fueron diluidas a $10 \mathrm{ng} / \mu \mathrm{L}$ y la calidad de la ADN fue evaluada en electroforesis en gel de agarosa $1 \%$ utilizando tampón TBE $1 \mathrm{X}(500 \mathrm{mM}$ Tris- $\mathrm{HCl}$, $60 \mathrm{mM}$ ácido bórico y $83 \mathrm{mM}$ EDTA) a $70 \mathrm{~V}$ por una hora. El gel fue visualizado bajo radiación UV después del tratamiento con Bromuro de etidio $(0.5 \mathrm{mg} / \mathrm{ml})$ por una hora. Luego, la imagen fue fotografiada utilizando el programa Kodak EDAS (Kodak 1D Análisis de Imagen 3.5, EUA). 
The reactions were amplified in Eppendorf Mastercycler Gradient (EUA), and the cycles were based on the species. L. elongatus and $S$. brasiliensis had the DNA denaturized at $96^{\circ} \mathrm{C}$ for 5 min and soon after was conducted 40 cycles of $1 \mathrm{~min}$ at $94^{\circ} \mathrm{C}, 1 \mathrm{~min}$ and $30 \mathrm{~s}$ annealing the primer at $36^{\circ} \mathrm{C}$ and extension at $72^{\circ} \mathrm{C}$ for $2 \mathrm{~min}$. Thereafter, the final extension was at $72^{\circ} \mathrm{C}$ for 7 min. Otherwise, $R$. quelen had DNA denaturized at $92^{\circ} \mathrm{C}$ for $4 \mathrm{~min}$ and soon after was conducted 40 cycles of $1 \mathrm{~min}$ at a $92^{\circ} \mathrm{C}, 1 \mathrm{~min}$ of annealing at $40^{\circ} \mathrm{C}$ and $2 \mathrm{~min}$ at $72^{\circ} \mathrm{C}$ for extension. Soon after, was did the final extension at $72^{\circ} \mathrm{C}$ for $5 \mathrm{~min}$. Finally, $P$. fasciatum had amplification programmed for 40 cycles, with one initial step of denaturation at $95^{\circ} \mathrm{C}$ for $5 \mathrm{~min}$ and the final step at $72^{\circ} \mathrm{C}$ for 7 min. Every cycle had $1 \mathrm{~min}$ at $94^{\circ} \mathrm{C}, 1 \mathrm{~min}$ at $36^{\circ} \mathrm{C}$ and two min at $72^{\circ} \mathrm{C}$. Twenty five primers from the Kits OPA, OPW and OPX (Operon Technologies Ltd., Valencia, USA) with 10 bases for every species were tested, when those of best definition and reproducibility were chosen (Table 1 ).

The amplified products were separated in agarose gel at $1.5 \%$ using horizontal electrophoresis. Fifteen microliters of amplified product in conjunction with $2 \mu \mathrm{L}$ of sample buffer ( $40 \%$ sucrose and $0.25 \%$ bromophenol blue) were inserted into the gel. This electrophoresis was carried out in buffer TBE $0.5 \mathrm{X}$ ( $45 \mathrm{mM}$ Tris-Borate and $1 \mathrm{mM}$ EDTA) at $70 \mathrm{~V}$ for 4 hours. The quantification and amplification gel were visualized under UV radiation after ethidium bromide dyeing $(0.5 \mu \mathrm{g} / \mathrm{mL})$ for 1 hour. The images were photographed using the program EDAS (Kodak 1D Image Analysis 3.5, New York, USA).

Computer software and statistical analysis. The size of the fragments was estimated by comparing them to the standard ladder of 100 bp (Invitrogen, Carlsbad, USA). The presence or absence of fragments with similar molecular size was used to build a similarity matrix based on the Jaccard coefficient where 1 was the presence and 0 was the absence. The percentage of polymorphic fragments ( $95 \%$ criterion), the Shannon's index and the genetic diversity of Nei were calculated by the PopGene 1.31 program (17).

\section{RESULTS}

The 25 primers (Table 1 ) had different amplification standards for every fish species. A total of 440 fragments from $100 \mathrm{bp}$ (OPW14-Pseudoplatystoma fasciatum) to 2900 bp (OPW03 - Leporinus elongatus) were amplified. The total number of fragments and number of polymorphic fragments were different among the species. In $L$. elongatus, 107 in 124 fragments were polymorphic; $S$.
EI ADN fue amplificado en volumen de reacción de $15 \mu \mathrm{L}$ utilizando tampón $1 \mathrm{X}$ Tris- $\mathrm{KCl}, 2 \mathrm{mM}$ de $\mathrm{MgCl}_{2}, 0.46 \mu \mathrm{M}$ de iniciador, $0.2 \mathrm{mM}$ de cada dNTP, una unidad de Platinum Taq DNA polimerasa (Invitrogen, Carlsbad, EUA), y 10 ng de ADN objetivo.

Las reacciones fueron amplificadas en termociclador Eppendorf Mastercycler Gradient (EUA), y los ciclos se basaron en las especies. L. Elongatus y $S$. Brasilensis tuvieron el ADN desnaturalizado a $96^{\circ} \mathrm{C}$ por 5 min y poco después se llevaron a cabo 40 ciclos de 1 min a $94^{\circ} \mathrm{C}, 1 \mathrm{~min}$ y $30 \mathrm{seg}$ de ligación del iniciador a $40^{\circ} \mathrm{C}$ y 2 min a $72^{\circ} \mathrm{C}$ de extensión. Poco después, fue realizada la extensión final a $72^{\circ} \mathrm{C}$ por 5 min. De otro modo, $R$. quelen tuvo el ADN desnaturalizado a $92^{\circ} \mathrm{C}$ durante 4 min y poco después se llevaron a cabo 40 ciclos de 1 min a $72^{\circ} \mathrm{C}$ para la extensión. Posteriormente, se hizo la extensión final a $72^{\circ} \mathrm{C}$ durante $5 \mathrm{~min}$. Finalmente, $P$. Fasciatum tuvo amplificación programada para 40 ciclos, con un paso inicial de desnaturalización de $95^{\circ} \mathrm{C}$ por 5 min y un paso final de $72^{\circ} \mathrm{C}$ por 7 min. Cada ciclo tuvo $1 \mathrm{~min}$ a $94^{\circ} \mathrm{C}, 1 \mathrm{~min}$ a $36^{\circ} \mathrm{C}$ y $2 \mathrm{~min}$ a $72^{\circ} \mathrm{C}$. Veinticinco iniciadores de los kits OPA, OPW y OPX (Operon Technologies Ltd Valencia, EUA), con 10 bases para cada especie fueron probados, y aquellos de mejor definición y reproductibilidad fueron escogidos (Tabla 1 ).

Los productos amplificados se separaron en gel de agarosa al $1.5 \%$ en el uso de electroforesis horizontal. Quince micro-litros de producto amplificado en conjunción con $2 \mu \mathrm{L}$ de tampón de muestra ( $40 \%$ de sacarosa y $0.25 \%$ de azul de bromofenol) se insertaron en el gel. Esta electroforesis se realizó en tampón TBE $0.5 \mathrm{X}$ ( $45 \mathrm{mM}$ Tris Borato y $1 \mathrm{mM}$ EDTA) a $70 \mathrm{~V}$ por 4 horas. El gel de cuantificación y amplificación fue visualizado bajo radiación UV luego de tinción con bromuro de etidio $(0.5 \mu \mathrm{g} / \mathrm{mL})$ por una hora. Las imágenes fueron fotografiadas utilizando para el programa EDAS (Kodak 1D Análisis de Imagen 3.5, EUA).

Software de computador y análisis estadístico. El tamaño de los fragmentos se estimó comparándolos con la escala estándar de 100 bp (Invitrogen, Carlsbad, USA). La presencia o ausencia de fragmentos con tamaño molecular similar fue utilizada para construir una matriz de similaridad basada en el coeficiente de Jaccard donde 1 era la presencia 0 era la ausencia. El porcentaje de fragmentos polimórficos (criterio de 95\%), el índice de Shannon y la diversidad genética de Nei se calcularon con el programa PopGene 1.31 (17). 
Table 1. Nucleotide sequences and percentage of $\mathrm{G}+\mathrm{C}$ bases of the primers amplified for the Leporinus elongatus, Salminus brasiliensis, Rhamdia quelen and Pseudoplatystoma fasciatum broodstocks.

\begin{tabular}{|c|c|c|}
\hline Primers & Nucleotide sequences & $\begin{array}{l}\text { Percentage } \\
\text { of } \mathbf{G}+\mathbf{C}\end{array}$ \\
\hline OPA02 & 5'-TGCCGAGCTG-3' & 70 \\
\hline OPA05 & 5'-AGGGGTCTTG-3' & 60 \\
\hline OPA10 & 5'-GTGATCGCAG-3' & 60 \\
\hline OPA16 & 5'-AGCCAGCGAA-3' & 60 \\
\hline OPW01 & 5'-CTCAGTGTCC-3' & 60 \\
\hline OPW02 & 5'-ACCCCGCCAA-3' & 70 \\
\hline OPW03 & 5'-GTCCGGAGTG-3' & 70 \\
\hline OPW04 & 5'-CAGAAGCGGA-3' & 60 \\
\hline OPW05 & 5'-GGCGGATAAG-3' & 60 \\
\hline OPW06 & 5'-AGGCCCGATG-3' & 70 \\
\hline OPW08 & 5'-GACTGCCTCT-3' & 60 \\
\hline OPW09 & 5'-GTGACCGAGT-3' & 60 \\
\hline OPW11 & 5'-CTGATGCGTG-3' & 60 \\
\hline OPW14 & 5'-CTGCTGAGCA-3' & 60 \\
\hline OPW15 & 5'-ACACCGGAAC-3' & 60 \\
\hline OPW19 & 5'-CAAAGCGCTC-3' & 60 \\
\hline OPXO1 & 5'-CTGGGCACGA-3' & 70 \\
\hline OPX02 & 5'-TTCCGCCACC-3' & 70 \\
\hline OPX03 & 5'-TGGCGCAGTG-3' & 70 \\
\hline OPX06 & 5'-ACGCCAGAGG-3' & 70 \\
\hline OPX07 & 5'-GAGCGAGGCT-3' & 70 \\
\hline OPXO9 & 5'-GGTCTGGTTG-3' & 60 \\
\hline OPX12 & 5'-TCGCCAGCCA-3' & 70 \\
\hline OPX13 & 5'-ACGGGAGCAA-3' & 60 \\
\hline OPX17 & $5^{\prime}$-GACACGGACC- $3^{\prime}$ & 70 \\
\hline
\end{tabular}

brasiliensis had 76 in 105; R. quelen had 128 in 134 fragments, being the highest number of fragments and percentage detected in the current experiment. Finally, $P$. fasciatum had 71 in 77 fragments (Table 2).

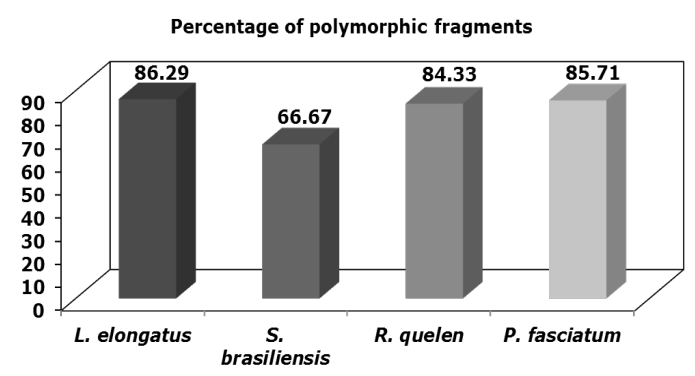

\section{RESULTADOS}

Los 25 iniciadores (Tabla 1) tuvieron diferentes estándares de amplificación para cada especie de pez. Un total de 440 fragmentos de 100 pb (OPW14 - Pseudoplatystoma fasciatum) a $2.900 \mathrm{pb}$ (OPW03 - Leporinus elongatus) fueron amplificados. El número total de fragmentos y el número de fragmentos polimórficos fue distinto entre las especies. En L. elongatus, 107 de 124 fragmentos fueron polimórficos; S. brasiliensis tuvo 76 en 105; R. quelen tuvo 128 en 134 fragmentos, siendo el mayor número de fragmentos y porcentajes detectado en el presente experimento. Finalmente, $P$. fasciatum tuvo 71 en 77 fragmentos (Tabla 2).

Con relación al porcentaje de fragmentos polimórficos se encontraron valores altos para todas las especies $(66.67 \%$ al $86.29 \%)$. Los valores del índice de Shannon fueron igualmente altos. Los resultados de la diversidad genética de Nei mostraron altas estimaciones que van de 0,248 (S. brasiliensis) a 0.331 ( $R$. quelen) (Figura 1).

\section{DISCUSIÓN}

El número total de fragmentos encontrados concuerda con las conclusiones de Telles et al. (2001) que determinaron mayor importancia del número de fragmentos obtenidos (como mínimo 50) que el número de iniciadores utilizados para el cálculo de la diversidad genética.

El porcentaje de fragmentos polimórficos, índice de Shannon y parámetros de diversidad genética de Nei indicaron una alta variabilidad genética que es esencial para un buen desempeño de programas de repoblación. Alelos perdidos de resistencia a enfermedades y reducciones en la capacidad de adaptación son consecuencias de la reducción de variabilidad genética (14). Los datos publicados de marcadores moleculares con las mismas especies estudiadas se muestran en la tabla 3 . No se encontraron referencias a $P$.

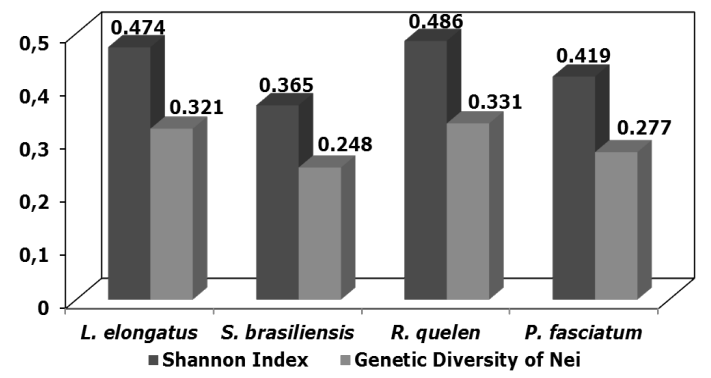

Figure 1. Percentage of polymorphic fragments, Shannon index, and the genetic diversity of Nei Leporinus elongatus, Salminus brasiliensis, Rhamdia quelen and Pseudoplatystoma fasciatum broodstocks. 
Table 2. Fragment number, number of polymorphic fragments and size of amplified fragments for Leporinus elongatus, Salminus brasiliensis, Rhamdia quelen and Pseudoplatystoma fasciatum broodstocks.

\begin{tabular}{|c|c|c|c|c|c|c|c|c|c|c|c|c|}
\hline \multirow[t]{2}{*}{ Primers } & \multicolumn{3}{|c|}{ Leporinus elongatus } & \multicolumn{3}{|c|}{ Salminus brasiliensis } & \multicolumn{3}{|c|}{ Rhamdia quelen } & \multicolumn{3}{|c|}{$\begin{array}{c}\text { Pseudoplatystoma } \\
\text { fasciatum }\end{array}$} \\
\hline & NF & NFP & $\mathbf{T}$ & NF & NFP & $\mathbf{T}$ & NF & NFP & $\mathbf{T}$ & NF & NFP & $\mathbf{T}$ \\
\hline OPA02 & - & - & - & 17 & 17 & $200-2072$ & 17 & 17 & $320-1900$ & - & - & - \\
\hline OPA05 & - & - & - & - & - & - & 13 & 12 & $300-1600$ & - & - & - \\
\hline OPA10 & - & - & - & - & - & - & - & - & - & 11 & 11 & $200-1200$ \\
\hline OPA16 & 14 & 13 & $300-2500$ & 12 & 09 & $300-2500$ & - & - & - & 08 & 08 & $250-1300$ \\
\hline OPW01 & 17 & 12 & $400-2500$ & - & - & - & - & - & - & - & - & - \\
\hline OPW02 & - & - & - & - & - & - & - & - & - & 11 & 10 & $300-2072$ \\
\hline OPW03 & 15 & 13 & $480-2900$ & - & - & - & - & - & - & - & - & - \\
\hline OPW04 & 18 & 17 & $400-2800$ & - & - & - & - & - & - & - & - & - \\
\hline OPW05 & - & - & - & - & - & - & - & - & - & 09 & 08 & $200-1400$ \\
\hline OPW06 & - & - & - & - & - & - & 21 & 20 & $300-2072$ & - & - & - \\
\hline OPW08 & 18 & 17 & $350-2400$ & - & - & - & 18 & 18 & $400-1800$ & - & - & - \\
\hline OPW09 & - & - & - & - & - & - & 20 & 18 & $420-1900$ & - & - & - \\
\hline OPW11 & - & - & - & - & - & - & 12 & 12 & $420-1800$ & - & - & - \\
\hline OPW14 & - & - & - & - & - & - & - & - & - & 10 & 09 & $100-1200$ \\
\hline OPW15 & - & - & - & - & - & - & 16 & 15 & $500-1900$ & - & - & - \\
\hline OPW19 & 14 & 11 & $300-2072$ & - & - & - & - & - & - & 13 & 11 & $400-2072$ \\
\hline OPXO1 & 13 & 10 & $300-2200$ & 11 & 06 & $550-2500$ & - & - & - & - & - & - \\
\hline OPX02 & - & - & - & - & - & - & - & - & - & 08 & 07 & $200-1600$ \\
\hline OPX03 & 15 & 14 & $500-2500$ & - & - & - & - & - & - & - & - & - \\
\hline OPX06 & - & - & - & 13 & 05 & $400-2072$ & - & - & - & - & - & - \\
\hline OPX07 & - & - & - & 12 & 09 & $600-2072$ & - & - & - & - & - & - \\
\hline OPXO9 & - & - & - & 19 & 13 & $200-2600$ & - & - & - & - & - & - \\
\hline OPX12 & - & - & - & 08 & 07 & $700-2072$ & - & - & - & - & - & - \\
\hline OPX13 & - & - & - & 13 & 10 & $400-2072$ & - & - & - & - & - & - \\
\hline OPX17 & - & - & - & - & - & - & 17 & 16 & $430-2072$ & 07 & 07 & $250-1300$ \\
\hline Total & 124 & 107 & $300-2900$ & 105 & 76 & $200-2600$ & 134 & 128 & $100-2072$ & 77 & 71 & $100-2072$ \\
\hline
\end{tabular}

NF: Fragment number; NFP: number of polymorphic fragments; T: size (bp).

About the percentage of polymorphic fragments high values were found for all the species ( $66.67 \%$ to $86.29 \%)$. The Shannon index values were similarly high. The results from the genetic diversity of Nei showed high estimates, ranging from 0.248 (S. brasiliensis) to 0.331 ( $R$. quelen) (Figure 1).

\section{DISCUSSION}

The total number of fragments found is consistent to the conclusions of Telles et al. (18) that determined the most important number of fragments obtained (at least 50) than the number of primers used for the calculation of genetic diversity.

The percentage of polymorphic fragments, Shannon index and genetic diversity of Nei parameters indicated high genetic variability that is essential for a good performance of restocking programs. Losses alleles of disease resistance and reduction in the adaptation capacity are consequences of dropping in the genetic variability (14). Literature data from molecular markers with the same studied species are displayed in the table 3 . References to $P$. fasciatum were not found and only one fasciatum y solo un manuscrito para $R$. quelen fue reportado.

Con relación al porcentaje de fragmentos polimórficos (PFP) y el índice de Shannon (IS) de otros artículos (Tabla 3), sólo el PFP de $R$. quelen encontrados por Lidani et al (19) fue mayor que aquel encontrado en la investigación actual. Ambos parámetros (PFP y IS) fueron un poco menores en todos los artículos de $L$. elongatus y mucho más pronunciados para S. brasiliensis.

Table 3. Variability and genetic diversity using molecular markers in $L$. elongatus, $S$. brasiliensis and $R$. quelen.

\begin{tabular}{ccccc}
\hline Authors & Species & \%FP & IS & DGN \\
\hline$(19)$ & R. quelen & 93.9 & - & - \\
$(20)$ & S. brasiliensis & $42.19-44.79$ & - & 0.018 \\
$(8)$ & L. elongatus & $81.3-88.8$ & $0.4086-0.4470$ & $0.0234-0.1224$ \\
$(22)$ & L. elongatus & 76.74 e 86.96 & $0.425-0.444$ & - \\
$(14)$ & S. brasiliensis & 51.04 & 0.2805 & 0.268 \\
$(23)$ & S. brasiliensis & $33.33-71.43$ & $0.174-0.382$ & $0.198-0.372$ \\
$(10)$ & L. elongatus & $70.6-82.6$ & - & 0.086 \\
$(28)$ & S. brasiliensis & $36.14-48.02$ & - & 0.1612 \\
\hline
\end{tabular}

\%FP: percentage of polymorphic fragments; IS: Shannon index; DGN: Genetic diversity of Nei 
manuscript to $R$. quelen was reported. Not all the cited references available had evaluated the same parameters investigated in the current experiment.

About the percentage of polymorphic fragments (PPF) and Shannon index (SI) from other manuscripts (Table 3), just the percentage of polymorphic fragments of $R$. quelen found by Lidani et al (19) was higher than was found in the current investigation. Both parameters (PPF and SI) were slightly lower in all manuscripts about $L$. elongatus and much more pronounced for $S$. brasiliensis. Most of the samples evaluated by these authors were collected in Paranapanema River. Working with S. brasiliensis, Lopes et al (20) stated that the genetic variability found in their stocks was the consequence of the small population in the sites where these fish were collected (Canoas complex, Paranapanema River). Thus, despite the river from where was collected the specimens of L. elongatus and S. brasiliensis had been the same the founder effect may have had influence on the genetic variability. Based on Kang et al (21), the small effective number of parental fish in the stock formation may eliminate low frequent alleles, and consequently reducing the genetic variability. This was the factor reported by Lopera Barrero et al (22) which induced high variability in Prochilodus lineatus because the stocks investigated were formed by fish populations from different Rivers. Similarly, Gomes et al (23) found low genetic variability in a group of seven $S$. brasiliensis with $33.33 \%$ of polymorphic fragments and Shannon index of 0.174 , the lowest values found in these groups.

The genetic diversity of Nei is a parameter which determines the level of population differentiation. Based on the values obtained in this study, it can be affirmed that there was high heterogeneity between stocks, suggesting that they do not have a common origin. For this parameter, the values expressed in table 3 were classified from low to very high. Based on low values of genetic diversity (0.086), Ramos et al (10) stated that groups collected different periods in the transposition ladder of the UHE in Canoas I and Canoas II were part of only one population with several sub-populations. Similar conclusion was found by Lopez et al (20) to observe a value of 0.018 . They also stated that this and other groups were structured in just one population from Capivara reservoir

The efficiency of restocking programs has also to be highlighted beyond proper genetic variability, i.e. the program intensity, number of parents using in the mating, mating system, general management, and the genetic differentiation between wild and broodstock populations.
La mayoría de las muestras evaluadas por estos autores fue recolectada en el río de Paranapanema. Trabajando con S. Brasiliensis, lopes et al (20) declaró que la variabilidad genética encontrada en sus poblaciones fue la consecuencia de la población pequeña en los sitios donde estos peces fueron recolectados. (Complexo de Canoas, Río Paranapanema). Entonces, a pesar de que el río donde los especímenes de L. Elongatus y $S$. Brasiliensis fueron recolectados fue el mismo, el efecto fundador pudo tener una influencia en la variabilidad genética. Con base en Kang et al (21), el pequeño número efectivo de peces parentales en la formación del lote puede eliminar alelos de baja frequencia, y consecuentemente reducir la variabilidad genética. Este fue el factor reportado por Lopera Barrero et al (22) que indujo una alta variabilidad en Prochilodus lineatus debido a que los lotes investigados se formaron con poblaciones de peces de distintos Ríos. Similarmente, Gomes et al (23) encontraron baja variabilidad genética en un grupo de siete S. Brasiliensis con $33.33 \%$ de fragmentos polimórficos y un índice de Shannon de 0.174 , los menores valores encontrados en estos grupos.

La diversidad genética de Nei es un parámetro que determina el nivel de diferenciación entre poblaciones. Con base en los valores obtenidos en el presente estudio, puede afirmarse que hubo alta heterogeneidad entre los lotes, sugiriendo que los mismos no presentan una origen en común. Para este parámetro, los valores expresados en la tabla 3 fueron clasificados de bajos a muy altos. Con base en los bajos valores de diversidad genética (0.086), Ramos et al (10) declaro que grupos recolectados en diferentes periodos en la escalera de transposición de UHE en Canoas I y Canoas II fueron parte de sólo una población con distintas subpoblaciones. Una conclusión similar fue encontrada por Lopes et al (20) al observar un valor de 0.018 . También establecieron que este y otros grupos fueron estructurados en sólo una población del reservatorio Capivara.

La eficiencia de los programas de repoblación también ha sido resaltada más allá de la variabilidad genética, ej. la intensidad del programa el número de padres utilizado en el apareamiento, el sistema de apareamiento, manejo general, y la diferenciación genética entre poblaciones naturales y lotes de reproductores.

Evaluando la intensidad de repoblación de Salvelinus fontinalis en la diversidad genética de poblaciones naturales, Marie et al (24) estableció que en lagos con mayor intensidad había mayores niveles de diversidad, probablemente debido a la introducción de alelos domésticos. No obstante, Lopera Barrero 
Evaluating the intensity of restocking of Salvelinus fontinalis on the genetic diversity of wild populations, Marie et al (24) stated that in the lakes with higher intensity had higher levels of diversity, likely because of the introduction of domestic alleles. However, Lopera Barrero et al (22) reported the importance of genetic monitoring of populations to avoid losses in genetic variability (outbreeding depression), while preventing the introduction of genetic material com high genetic differentiation in relation to the wild population.

On the other hand, showing the negative effect of impropriated number of parents, MachadoSchiaffino et al (25) reported the variability losses in juveniles of Atlantic salmon (Salmo salar L.) from restocking programs in comparison to wild populations likely because the bottleneck effect caused by the reduced number used in breeding matings. In contrast, Lopera-Barrero et al (26) stabilized the variability using 24 parental fish (12 males and 12 females) of Brycon orbignyanus showing the positive effect of adequate number of parents, despite the semi-natural reproductive system that also had influence in maintain the genetic variability.

Another factor with influence in the genetic variability of fish stocks has been the mating system. Gomes et al (14) found higher estimates of genetic variability in the progeny of $S$. brasiliensis than in the parental fish using the semi-natural reproductive system. When evaluating the paternity of progeny Brycon orbignyanus in semi-natural and extrusion reproductive systems, Lopera Barrero et al (27) found multiple paternities and differentiated reproductive contribution in both systems. The authors, however, suggest more experiments to confirm the reproductive efficiency of semi-natural system in maintaining the genetic variability in other species.

The management of the offspring can also influence the genetic variability of restocking programs. Almeida et al (28) found that instead of releasing each offspring lot separately into the water, mixing specimens produced in the various fry stocks before releasing them in the river would be more feasible. The restocked population will have a genetic structure closer to wild populations. On the other hand, Rodriguez-Rodriguez et al (29) suggested that in the progeny aimed at restocking programs a first genetic analysis must be carried in the larval stage (3 days), which will provide a general overview of the new genetics generation. Then, at 60 or 90 days, depending on environmental conditions of the ecosystem should be performed a second analysis to objectively determine the final genetic variability with which individuals will be released into the river. This analysis should et al (22) reportó la importancia del monitoreo genético de las poblaciones para evitar pérdidas en la variabilidad genética (depresión exogámica), además de impedir la introducción de material genético con alta diferenciación genética en relación a la población natural.

Por otro lado, mostrando el efecto negativo de un número inapropiado de padres, Machado-Schiaffino et al (25) reportó la pérdida de variabilidad en juveniles de salmón atlántico (Salmo salar L.) de programas de repoblación en comparación con poblaciones naturales probablemente debido al efecto de cuello de botella causado por el reducido número de reproductores usado en los apareamientos. En contraste, Lopera Barrero et al (26) estabilizó la variabilidad utilizando un 24 peces parentales (12 machos y 12 hembras) de Brycon orbignyanus mostrando un efecto positivo en el número adecuado de padres, a pesar de que el sistema reproductivo seminatural también tuvo influencia en mantener la variabilidad genética.

Otro factor con influencia en la variabilidad genética de lotes de peces ha sido el sistema de apareamiento. Gomes et al (14) encontraron mayores estimados de variabilidad genética en la progenie de $\mathrm{S}$. Brasiliensis que en los peces parentales utilizando el sistema de reproducción seminatural. Cuando evaluada la paternidad de la progenie de Brycon orbignyanus en sistemas de reproducción seminatural y de extrusión, Lopera Barrero et al (27) encontró múltiples paternidades y contribución reproductiva diferenciada en ambos sistemas. Los autores, sin embargo, sugieren más experimentos para confirmar la eficiencia reproductiva del sistema seminatural para mantener la variabilidad genética en otras especies.

El manejo de la progenie también puede influenciar la variabilidad genética de programas de repoblación. Almeida et al (28) encontraron que en lugar de liberar cada lote de progenies de manera separada en el agua, mezclar los especímenes producidas en varios lotes antes de liberarlos en el río era más factible. La población repoblada tendrá una estructura genética cercana a la de las poblaciones naturales. Por otro lado, Rodriguez-Rodriguez et al (29) sugirió que en la progenie destinada a programas de repoblación un primer análisis genético debe realizarse en la etapa larval (3 días), lo que proporcionará una visión general de la nueva generación de la genética. Luego, a los 60 o 90 días, dependiendo de las condiciones ambientales del ecosistema, debe ser realizado un segundo análisis para determinar objetivamente la variabilidad genética final con la cual los individuos serán liberados en el río. Ese análisis debe ser realizada para determinar cuáles individuos serán liberados y determinar la verdadera viabilidad de repoblar.

Finalmente, la alta diferenciación genética entre poblaciones naturales y lotes de reproductores puede 
be performed to determine which individuals will be released and determine the true feasibility of restocking.

Finally, high genetic differentiation between wild and broodstocks can induce important gene losses associated with local adaptation. Similarly, González-Wangüemert et al (30) found high genetic differentiation between stocks of Diplodus sargus (for restocking the Castellamare gulf, Italy) and samples from the wild population. Based on these authors, this differentiation was likely verified by periodic inclusion of wild individuals from other places and the management adopted in captivity.

Based on the current results, the level of genetic variability in the $L$. elongatus, S. brasiliensis, $R$. quelen and $P$. fasciatum broodstocks are therefore adequate for allowing their use in restocking programs in the Paranapanema, Iguaçu and Paraná Rivers. However, periodical monitoring of the genetic variability of these stocks, the mating system, proper reproductive system and general management should be studied to guarantee the preservation of these wild populations.

\section{Acknowledgements}

The authors are thanks to the Duke Energy International for providing part of the biological material, and the researchers, technicians and students who supported the current experiment. inducir a pérdidas de genes importantes asociados con la adaptación local. Similarmente, González et al (30) encontró una alta diferenciación genética entre los lotes de Diplodus sargus (para repoblar el golfo de Castellamare, Italia) y muestras de la población natural. Con base en estos autores, la diferenciación fue posiblemente verificada por la inclusión periódica de individuos naturales de otros lugares y el manejo adoptado en cautiverio.

Con base en los presentes resultados, el nivel de variabilidad genética lotes de reproductores de $L$. elongatus, S. brasiliensis, R. quelen y P. Fasciatum es adecuado para permitir su uso en programas de repoblación en los Ríos Paranapanema, Iguaçu y Paraná. Sin embargo, el monitoreo periódico de la variabilidad genética de estas poblaciones, el sistema de apareamiento, el sistema reproductivo adecuado y el manejo general puede aún ser estudiada para garantizar la preservación de estas poblaciones naturales.

\section{Agradecimiento}

Los autores agradecen a Duke Energy International por proporcionar parte del material biológico y a los investigadores, técnicos y estudiantes que apoyaron el presente experimento.

\section{REFERENCES}

1. Fao - Food and Agriculture Organization of the United Nations. FAO yearbook. Fishery and Aquaculture Statistics, 2010. Rome, 2013.

2. Mpa - Ministério da Pesca e Aquicultura. Boletim Estatístico da Pesca e Aquicultura, 2011. Brasília, 2013.

3. Fao - Food and Agriculture Organization of the United Nations. FAO yearbook. Fishery and Aquaculture Statistics, 2009. Rome, 2011.

4. Lopera-Barrero NM, Ribeiro RP, Povh JA, Vargas-Mendez LD, Poveda-Parra AR. Produção de Organismos Aquáticos: uma visão geral no Brasil e no mundo. Guaíba: Agrolivros; 2011.

5. Crepaldi DV, Faria PMC, Teixeira EA, Ribeiro LP, Costa AAP, Melo DC. O surubim na aquacultura do Brasil. Rev Bras Reprod Anim 2006; 30:150-158.
6. Graça WJ, Pavanelli CS. Peixes da planície de inundação do alto rio Paraná e áreas adjacentes. Maringá: EDUEM; 2007.

7. Kutter MT, Bemvenuti MA, Moresco A. Feeding strategy of the jundiá Rhamdia quelen (Siluriformes, Heptapteridae) in costal lagoons of southern Brazil. Acta Sci Biol Sci 2009; 31:41-47.

8. Gomes PC, Ribeiro RP, Lopera-Barrero NM, Povh JA, Vargas L, Sirol RN. Diversidade genética de três estoques de piapara (Leporinus elongatus), utilizando RAPD. Acta Sci Anim Sci 2008; 30:241-247.

9. Agostinho AA, Pelicice FM, Gomes LC. Dams and the fish fauna of the Neotropical region: impacts and management related to diversity and fisheries. Braz J Biol 2008; 68:1119-1132. 
10. Ramos JVB, Sodré LMK, Orsi ML, Almeida FS. Genetic diversity of the species Leporinus elongatus (Teleostei: Characiformes) in the Canoas Complex - Paranapanema River. Neotrop Ichthyol 2012; 10:821-828.

11. Lopera Barrero NM. Conservation of Brycon orbignyanus natural populations and stocks for their reproductive, genetic, environmental sustainability: A model for species threatened with extinction. Cienc Inv Agr 2009; 36:191-208.

12. Povh JA, Ribeiro RP, Sirol RN, Streit JR DP, Moreira HLM, Siewerdt F et al. Microsatellite Analysis of the Parental Contribution of Piaractus mesopotamicus to the Production of Offspring in the Semi-natural System of Reproduction. Braz Arch Biol Technol 2010; 53:389-396.

13. Kalinowski ST, Doornik DMV, Kozfkay CC, Waples RS. Genetic diversity in the Snake River sockeye salmon captive broodstock program as estimated from broodstock records. Conserv Genet 2012; 13:1183-1193.

14. Gomes PC, Ribeiro RP, Sirol RN, Lopera Barrero NM, Moreira HLM, Povh JA et al. Diversidade genética de dourado utilizado em programas de repovoamento no rio Paranapanema. Pesq Agropec Bras 2011; 46:167-173.

15. Lopera Barrero NM, Povh JA, Fornari DC, Rodriguez Rodriguez M del P, Santos SCA, Ribeiro RP. Genetic diversity of Prochilodus lineatus stocks using in the stocking program of Tietê River, Brazil. Rev MVZ Córdoba 2013; 18:3759-3766.

16. Lopera-Barrero NM, Povh JA, Ribeiro RP, Gomes PC, Jacometo CB, Lopes TS. Comparison of DNA extraction protocols of fish fin and larvae samples: modified salt $(\mathrm{NaCl})$ extraction. Cienc Inv Agr 2008a; 35:65-74.

17. Yeh FC, Boyle TYZ, Xiyan JM. POPGENE Version 131: Microsoft Window-based freeware for population genetic analysis. (Consulta en internet) Alberta (Accesado mayo de 2014). 1999. URL Disponible en: http://www. ualberta.ca/ fyeh/popgene.pdf.

18. Telles MPC, Monteiro MSR, Rodrigues FM, Soares TN, Resende LV, Amaral AG et al. Marcadores RAPD na análise de divergência genética entre raças de bovinos e número de locos necessários para a estabilidade da divergência estimada. Cien Anim Bras 2001; 2:87-95.
19. Lidani KCF, Lima JR, Torres RA, Gabriel JE, Madeira HMF, Carneiro PCF. Variabilidade genética de um estoque cativo de Jundiá (Rhamdia quelen). Rev Acad 2006; 4:47-53.

20. Lopes CM, Almeida FS, Orsi ML, Britto SGC, Sirol RN, Sodré LMK. Fish passage ladders from Canoas Complex - Paranapanema River: evaluation of genetic structure maintenance of Salminus brasiliensis (Teleostei: Characiformes). Neotrop Ichthyol 2007; 5:131-138.

21. Kang JH, Noh JK, Kim JH, Lee JH, Kim HC, $\mathrm{Kim} \mathrm{KK}$ et al. Genetic relationship between broodstocks of olive flounder, Paralichthys olivaceus (Temminck and Schlegel) using microsatellite markers. Aqua Res 2006; 37:701-707.

22. Lopera Barrero NM, Ribeiro RP, Povh JA, Gomes PC, Vargas L, Oliveira SN. Caracterización genética de lotes de peces usados en programas de repoblamiento y su importancia en la conservación genética en la piscicultura. Zootecnia Trop 2008b; 26:515-522.

23. Gomes PC, Lopera Barrero NM, Vargas L, Streit Jr DP, Povh JA, Sirol RN et al. Genetic diversity of Salminus brasiliensis (Characiformes: Characidae) collected in the passage ladder of the Canoas I hydropower plant in the Paranapanema River, Brazil. Semin-Cienc Agrar 2013; 34:1421-1432.

24. Marie D, Bernatchez L, Garant D. Loss of genetic integrity correlates with stocking intensity in brook charr (Salvelinus fontinalis). Mol Ecol 2010; 19:2025-2037.

25. Machado-Schiaffino G, Dopico E, GarciaVazquez E. Genetic variation losses in Atlantic salmon stocks created for supportive breeding. Aquacult 2007; 264:59-65.

26. Lopera-Barrero NM, Vargas L, Sirol RN, Ribeiro RP, Povh JA, Mangolin CA. Caracterização genética de Brycon orbignyanus utilizando o sistema seminatural. Arq Bras Med Vet Zootec 2010; 62:184-191.

27. Lopera-Barrero NM, Reyez Alvarez CA, Rodriguez-Rodriguez MP, Povh JA, Vargas L, Streit Jr DP et al. Diversidade genética e paternidade de progênies de Brycon orbignyanus obtidas por diferentes sistemas reprodutivos. Semin-Cienc Agrar 2014; 35:541-554. 
28. Almeida FS, Lopes CM, Orsi ML, Sirol RN, Sodré LMK. Genetic monitoring by RAPD markers for repopulation programs of Salminus brasiliensis (Pisces, Characiformes). Acta Sci Anim Sci 2013; 35:119-126.

29. Rodriguez-Rodriguez MP, Lopera Barrero NM, Ribeiro RP, Povh JA, Vargas L, Sirol RN et al. Diversidad genética de piracanjuba usada en programas de repoblación con marcadores microsatélites. Pesq Agropec Bras 2010; 45:53-63.
30. Gonzáles-Wangüemert M, Fernández TV, Pérez-Rufaza A, Giacalone M, D'anna G, Badalamenti F. Genetic considerations on the introduction of farmed fish in marine protected areas: The case of study of white seabream restocking in the Gulf of Castellammare (Southern Tyrrhenian Sea). J Sea Res 2012; 28:41-48. 